\title{
Wpływ warunków napawania obręczy kół zestawów kolejowych na właściwości warstw
}

\section{Influence of the hoop wheels hard-facing conditions on the weld metal properties}

\section{Streszczenie}

Określono wpływ wybranych warunków napawania obręczy kół wykonanych ze stali P60T, kolejowych zestawów kołowych na właściwości napoin. Obręcze napawano łukiem krytym drutem SpG4N wraz z topnikiem TASt6. Napoiny poddano badaniom metalograficznym makro- i mikroskopowym oraz określono rozkład twardości na przekroju obręczy. Uzyskane wyniki pozwalają stwierdzić, że przy zachowaniu ściśle określonych warunków technologicznych procesu możliwe jest napawanie obręczy ze stali P60T i uzyskanie dobrych właściwości mechanicznych.

\section{Abstract}

The influence of selected conditions surfacing of hoop wheels made of steel P60T railway wheel sets on the properties of weld metal was investigated. Submerged arc with the wire SpG4N and flux TASt6 to surfacing of the wheel hoops was applied. Metallographic macro- and microscopic investigations were carried out. The distribution of the hardness on the hoops sections were determined. The results obtained allow to conclude that, under strictly defined conditions of technological process, it is possible hard-facing of hoops made of steel P60T and achieve good mechanical properties.

\section{Wstęp}

Stosowanie na obręcze kolejowych zestawów kołowych stali P60T miało na celu zwiększenie czasu eksploatacji kół. Zagadnienie ponownego profilowania zużytej obręczy jest podobne jak w przypadku obręczy z innych stali P54, P55 itp. i jest związane zwłaszcza z du-

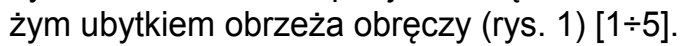

W skrajnych przypadkach zużycia możliwe jest jedynie dwukrotne reprofilowanie zarysu obręczy, jeśli nie stosuje się napawania. Natomiast dzięki napawaniu możliwe jest nawet siedmiokrotne reprofilowanie zarysu obręczy. Wydatnie zwiększyłoby to czas eksploatacji obręczy w zestawie i zmniejszyłoby liczbę kosztownych przeobręczowań.

Niezależnie od gatunku stali problem zużywania się obręczy będzie istniał zawsze. Związane są z tym

Dr inż. Piotr Białucki, dr inż. Stefan Kozerski - Politechnika Wrocławska. koszty, np. ponownego profilowania zarysu obręczy, wywiązywania kół z wózka, ponownego obręczowania itp. Można próbować je obniżyć, stosując automatyczne napawanie łukowe.

Problemy pojawiające się przy napawaniu zwiększają się wraz ze wzrostem zawartości węgla w stali. W porównaniu ze stalą np. P55 zawartość węgla w stali P60T jest większa tylko ok. 0,05\%, jednak przy ogólnie wysokiej zawartości węgla w stali wynoszącej ok. 0,60\% problem spawalności staje się bardzo istotny. Zwiększona zawartość węgla wpływa na wzrost hartowności stali (stal P60T jest przeznaczona do ulepszania cieplnego), co sprzyja występowaniu martenzytu w strefie wpływu ciepła i niebezpiecznemu wzrostowi twardości powyżej $350 \mathrm{HV}$. Skurczowe połączenie obręczy z kołem bosym stwarza poważny problem wynikający z konieczności wstępnego podgrzania przed napawaniem. Łatwo może wtedy dojść do obluzowania się obręczy, co eliminuje ją z możliwości regeneracji napawaniem, pozostaje wówczas tylko operacja ponownego przeobręczowania koła. 


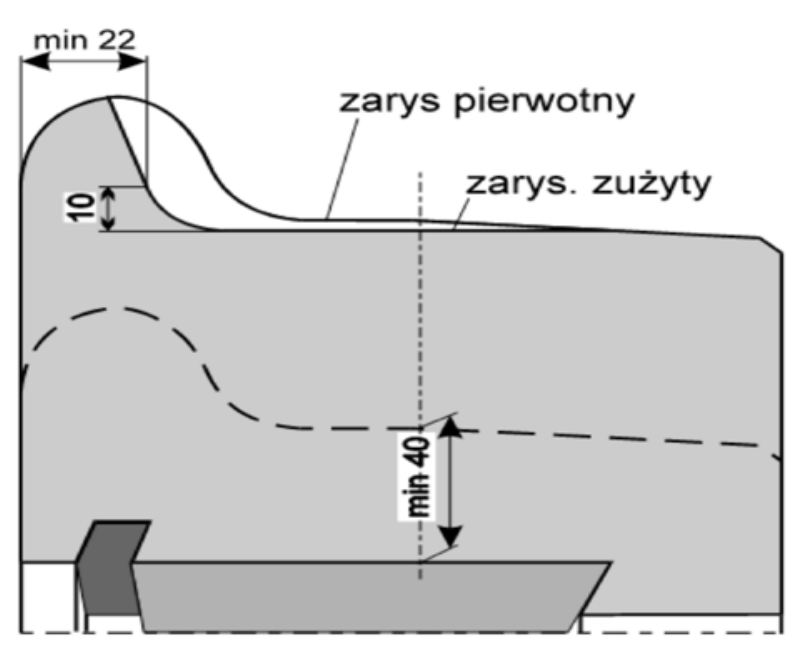

Rys. 1. Kwalifikacja zużytej obręczy do napawania

Fig. 1. Wear wheel hoop qualifying for hard-facing

\section{Materiały użyte do badań}

W tablicy I zestawiono wyniki analizy chemicznej badanej obręczy z zawartością składników stopowych w stali P60T wg normy PN-84/H-84027/06. Analize wykonano na spektrometrze LECO. Miejsce wykonania analizy na obręczy pokazano na rysunku 2a.

Jak widać $z$ tablicy I, analiza chemiczna wykazała dużą ilość węgla w stali, ale zawartości innych pierwiastków mieszczą się w granicach określonych normą. Zawartość fosforu i siarki w stali jest niewielka, co jest bardzo korzystne z punktu widzenia spawalności stali, natomiast wysoka zawartość węgla, wynosząca ponad $0,60 \%$, sprzyja pęknięciom na zimno, kwalifikuje materiał do grupy stali niespawalnych i podczas napawania może być przyczyną dużych trudności technologicznych.

Analiza składu chemicznego drutu użytego do badań wykazała zwiększoną zawartość krzemu w porównaniu z zawartością określoną w normie (tab. II). Próbkę drutu przygotowaną do analizy chemicznej pokazano na rysunku $2 b$.

Do osłony łuku podczas napawania obręczy użyto topionego topnika kwaśnego wysokomanganowego
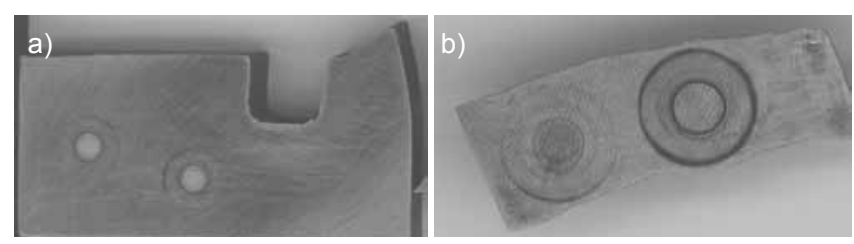

Rys. 2. Próbi przygotowane do analizy składu chemicznego na spektrometrze LECO: a) z obręczy ze stali P60T, b) próbka drutu SpG4N Fig. 2. Sample for chemical composition analysis with the use of LECO spectrometer: a) P60T hoop wheel, b) SpG4N wire

Tablica III. Skład chemiczny topnika TA.St. 6 MA

Table. III. Chemical composition of the TA.St. 6 MA flux

\begin{tabular}{|c|c|c|c|}
\hline \multirow{2}{*}{ Gat. topnika } & \multicolumn{3}{|c|}{ Zawartość składników, \% } \\
\cline { 2 - 4 } & $\mathrm{SiO}_{2}+\mathrm{TiO}_{2}$ & $\mathrm{Al}_{2} \mathrm{O}_{3}+\mathrm{MnO}+\mathrm{CaO}$ & $\mathrm{CaF}_{2}$ \\
\hline TA.St.6 & 40 & 50 & 3 \\
\hline
\end{tabular}

TA.St. 6 MA firmy EMA Brzezie. Główne składniki stopowe topnika podano $w$ tablicy III.

Topnik ten wykazuje bardzo dobre właściwości jonizacyjne, a w procesie spawania wprowadza mangan i krzem do spoiny. Według kwalifikacji MIS jego oznaczenie jest zblizzone do F12 ay 97 . Bardzo dobrze nadaje się do napawania, jego dobra płynność żużla korzystnie wpływa na kształt napoiny, a po skrzepnięciu żużel łatwo daje się usunąć. Topnik nadaje się do spawania prądem stałym lub przemiennym. Do napawania zastosowano źródło prądu przemiennego.

\section{Warunki napawania obręczy}

Badane obręcze kół wykonane ze stali P60T napawano automatycznie łukiem krytym zasilanym źródłem prądu TEP 800. Do napawania zastosowano drut SpG4N oraz topnik TA.St.6MA. Napawanie przeprowadzono dla dwóch zestawów parametrów spawania celem uzyskania różnej głębokości wtopienia w materiał rodzimy obręczy i różnego udziału materiału stopiwa w napoinie.

Tablica I. Zawartość pierwiastków stopowych w obręczy ze stali P60T Table I. Alloying elements fraction in the P60T wheel hoop

\begin{tabular}{|c|c|c|c|c|c|c|c|c|c|c|}
\hline \multirow{3}{*}{ Według } & \multicolumn{10}{|c|}{ Zawartość pierwiastków, \% } \\
\hline & \multirow{2}{*}{ C } & \multirow{2}{*}{$\mathrm{Mn}$} & \multirow{2}{*}{$\mathrm{Si}$} & $P$ & $S$ & $\mathrm{Cr}$ & $\mathrm{Ni}$ & $\mathrm{Cu}$ & Mo & V \\
\hline & & & & \multicolumn{7}{|c|}{$\max$} \\
\hline PN-84/H-84027/06 & $0,57 \div 0,65$ & $0,60 \div 0,90$ & $0,15 \div 0,40$ & 0,040 & 0,040 & 0,30 & 0,30 & 0,30 & 0,05 & 0,05 \\
\hline analizy chemicznej & 0,64 & 0,76 & 0,27 & 0,011 & 0,008 & 0,14 & 0,07 & 0,16 & 0,02 & 0,01 \\
\hline
\end{tabular}

Tablica II. Zawartość składników stopowych w drucie SpG4N

Table II. Alloying elements fraction in the SpG4N wire

\begin{tabular}{|c|c|c|c|c|c|c|c|c|c|}
\hline \multirow{2}{*}{ Według } & \multicolumn{9}{|c|}{ Zawartość pierwiastków, \% } \\
\hline & C & $\mathrm{Mn}$ & Si & $\mathrm{P}$ & $S$ & $\mathrm{Cr}$ & $\mathrm{Ni}$ & $\mathrm{Cu}$ & Mo \\
\hline PN-77/M-69420 & $\max .0,10$ & $1,60-2,00$ & 0,08 & 0,03 & 0,03 & 0,20 & $0,60-1,00$ & - & - \\
\hline analizy chemicznej & 0,08 & 1,84 & 0,21 & 0,010 & 0,016 & 0,06 & 0,73 & 0,14 & 0,01 \\
\hline
\end{tabular}


Parametry napawania wg wskazań mierników na szafce sterującej automatu były następujące:

$\begin{array}{lcc} & \begin{array}{c}\text { Dla pierwszej } \\ \text { warstwy }\end{array} & \begin{array}{c}\text { dla kolejnych } \\ \text { warstw }\end{array} \\ \text { Natężenie prądu spawania } & 370-400 \mathrm{~A} & 420-450 \mathrm{~A} \\ \text { Napięcie prądu } & 30 \mathrm{~V} & 30 \mathrm{~V}\end{array}$

Energia liniowa napawania pierwszej warstwy wynosiła ok. $10,5 \mathrm{~kJ} / \mathrm{cm}$, natomiast drugiej warstwy i następnych ok. $11,9 \mathrm{~kJ} / \mathrm{cm}$.

Obręcze podgrzewano wstępnie do temperatury $260^{\circ} \mathrm{C}$ - bieżnia oraz $242^{\circ} \mathrm{C}$ - czoło.

W ten sposób napoina na obręczy została ułożona na całej wysokości obrzeża po 8 obrotach zestawu kołowego. Pozostałe obręcze napawano z natężeniem

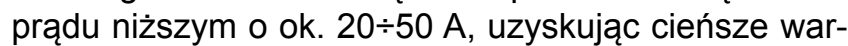
stwy, a napawanie zostało przerwane po dziesięciu obrotach zestawu kołowego, przy czym napoina osiągała ok. 4/5 wysokości obrzeża obręczy.

Również temperatura podgrzewania wstępnego była inna i wynosiła $235^{\circ} \mathrm{C}$ dla bieżni oraz $216^{\circ} \mathrm{C}$ dla powierzchni czołowej. Temperaturę kontrolowano pirometrami optycznymi w sposób ciągły i okresowo termoparą dotykową. Układ zestawu kołowego podczas napawania przedstawiono na rysunku 3.

Na rysunku 4 pokazano budowę napoin na obręczy kół uzyskanych przy różnych parametrach napawania odpowiadających energiom liniowym $10,8 \mathrm{~kJ} / \mathrm{cm}$ (rys. 4a) i 12,3 kJ/cm (rys. 4b). Napoiny różnią się wyraźnie grubością poszczególnych ściegów, głębokością wtopienia oraz nieznacznie szerokością ściegów. $Z$ różnic we wielkości wtopienia wynika różny stopień wymieszania materiału spoiwa z materiałem obręczy.

Z napawanych obręczy pobrano próbki do badań metalograficznych, pomiarów twardości oraz analizy składu chemicznego

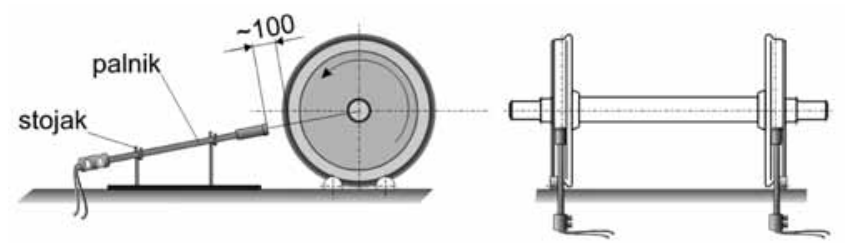

Rys. 3. Układ zestawu kołowego podczas napawania

Fig. 3. Wheel set during hard_facing
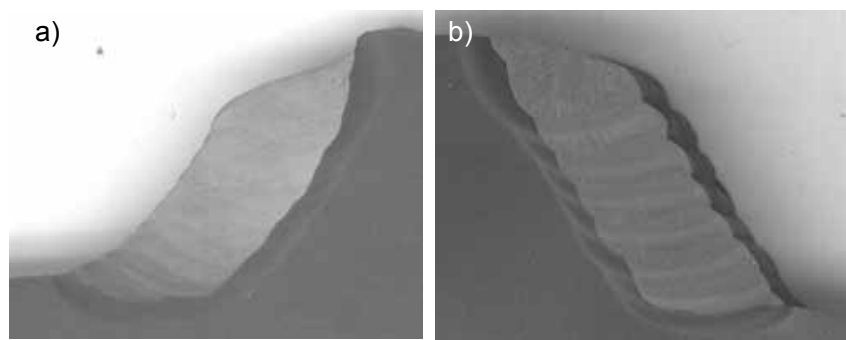

Rys. 4. Zarysy napoin na badanych obręczach ze stali P60T napawanych łukiem krytym drutem SpG4N z topnikiem TASt6M: a) napoina z dziesięcioma ściegami, b) napoina z ośmioma ściegami

Fig. 4. The contours of weld metal on P60T steel wheel hoops submerged arc hard facing with SpG4N wire and TASt6M flux, a) padding welds with 10 beads, b) padding welds with 8 beads

\section{Badania metalograficzne}

Z napawanych obręczy wycięto próbki do badań metalograficznych. Na rysunku 4 pokazano przykładowe przekroje napoin na dwóch obręczach.

Napoina pokazana na rysunku 4a składa się z dziesięciu cienkich warstw i nie wypełnia całego zarysu obrzeża obręczy, natomiast druga napoina, pokazana na rysunku 4b, została ułożona w ośmiu grubych warstwach i odtwarza pełny zarys obrzeża.

Na rys. 5 przedstawiono wygląd mikrostruktury materiału obręczy, a na rysunku 6 mikrostrukturę ostatniej warstwy napoiny ośmiowarstwowej.

W materiale rodzimym obręczy występuje struktura perlityczna z ferrytem (rys. 5). Widoczne są też pojedyncze drobne pory gazowe. Typowa mikrostruktura napoiny, występująca w obu obręczach, ma budowę dendrytyczną i składa się głównie z ferrytu o różnym stopniu nasilenia struktury Widmanstattena (rys. 7).

W badanych próbkach nie stwierdzono obecności pęknięć. Nie zaobserwowano też innych niezgodności materiałowych z wyjątkiem pojedynczych drobnych pęcherzy. W obu przypadkach napoin pomimo różnej liczby warstw, kształt poszczególnych ściegów oraz kształt wtopienia w materiał rodzimy oraz wtopienie międzywarstwowe są prawidłowe.

Łatwo można jednak zauważyć, że przy cieńszych warstwach mniejsze są obszary o strukturze dendrytycznej. Na rysunku 8 pokazano strukturę napoiny i SWC w materiale rodzimym w obręczy z dziesięciowarstwową napoiną.

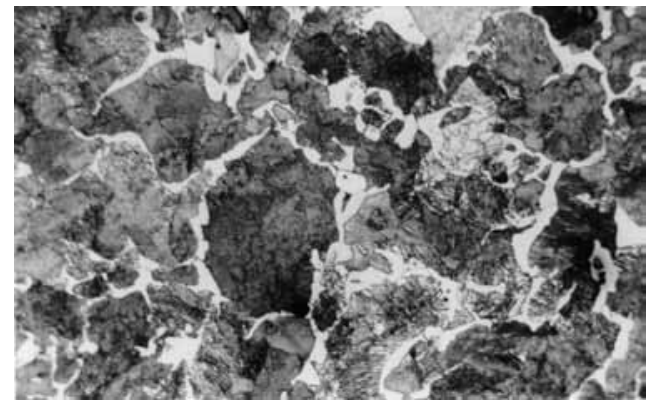

Rys. 5. Mikrostruktura materiału rodzimego napawanej obręczy (stal P60T). Trawiono Nitalem pow. 400x

Fig. 5. Microstructure of base metal of hard surfaced hoop wheel (P60T steel). Nital etching. Magn. 400x

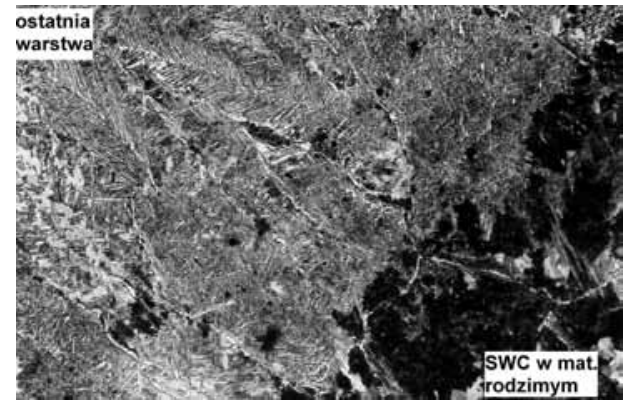

Rys. 6. Mikrostruktura ostatniej warstwy napoiny ośmiowarstwowej na materiale rodzimym obręczy ze stali P60T, trawiono Nitalem, pow. 200x

Fig. 6. Microstructure of the last layer of an eight-layer deposit on base metal of wheel hoop made of P60T steel. Nital etching. Magn. 200x 


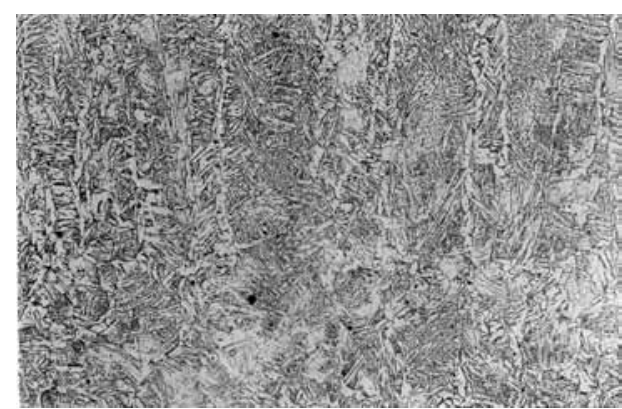

Rys. 7. Mikrostruktura ostatniej warstwy napoiny dziesięciowarstwowej. Trawiono Nitalem pow. 200x

Fig. 7. Microstructure of the last layer of a ten-layer deposit. Nital etching. Magn. 200x

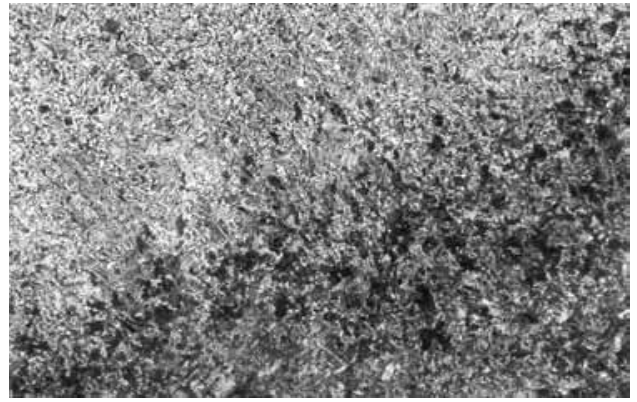

Rys. 8. Mikrostruktura SWC materiału rodzimego pod drugą warstwą napoiny dziesięciowarstwowej. Trawiono Nitalem, pow. 100x Fig. 8. HAZ microstructure of the base metal under a second layer of a ten-layer deposit. Nital etching. Magn. 100x

\section{Analiza chemiczna napoin}

Widoczne na rysunku 9 miejsca przyłożenia sondy podczas analizy chemicznej oznaczone cyframi 1', 2', 3 i 4 leżą w obszarze napoiny, pozostałą się znajduję w obszarze materiału obręczy. Wyniki analizy chemicznej zamieszczono w tablicy IV.

Porównując zawartość składników w drucie (tabl. II) i zawartość składników w napoinie, miejsca 1', 2', 3 i 4 (tab. V), można zauważyć, że występuje znaczne wymieszanie składników stopowych pochodzących z materiału drutu i materiału obręczy. Przykładowo
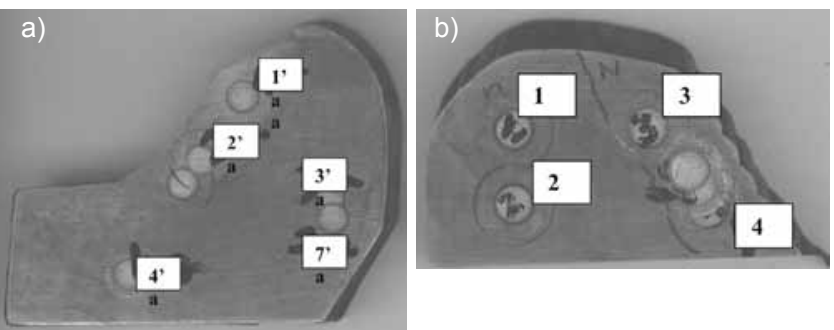

Rys. 9. Obszary napawanych obręczy, w których wykonano analizę składu chemicznego: a) napoina z dziesięcioma ściegami, b) napoina z ośmioma ściegami

Fig. 9. Areas of hard surfaced wheel hoop in which the chemical composition analysis was performed; a)weld metal with ten layers, b) weld metal with eight layers

w napoinie znajduje się więcej węgla niż w drucie oraz mniej manganu i niklu. Natomiast daje się zauważyć większą zawartość krzemu w napoinie zarówno w porównaniu z zawartością w drucie, jak i w obręczy, zatem źródłem dodatkowego krzemu może być topnik.

Zawartość pozostałych składników stopowych we wszystkich badanych materiałach odpowiada średniej i dolnej granicy określonej odpowiednią normą.

\section{Pomiary twardości}

Pomiary twardości wykonano wzdłuż linii przechodzących przez różne strefy obszaru napawania obejmującego niezmieniony strukturalnie materiał rodzimy obręczy, strefy wpływu ciepła napoiny oraz materiał napoiny w różnych warstwach. Wyniki pomiarów przedstawiono na rysunkach 10 i 11 .

Najwyższa twardość występuje w SWC materiału rodzimego pod pierwszą i ostatnią warstwą. Twardość pod pierwszą warstwą napoiny ośmiowarstwowej wynosi ok. 317 HV30 i jest zbliżona do twardości w napoinie dziesięciowarstwowej, która wynosi do 311 HV30. Odpowiednie twardości SWC pod ostatnią warstwą napoiny wynoszą $348 \mathrm{HV} 30$ w napoinie ośmiowarstwowej oraz 350 HV30 w napoinie dziesięciowarstwowej. Mimo stosunkowo wysokiej twardości nie stwierdzono w SWC

Tablica IV. Zawartość składników stopowych w napoinach i materiale obręczy

Table IV. The content of alloying elements in weld metal and wheel hoop material

\begin{tabular}{|c|c|c|c|c|c|c|c|c|c|c|}
\hline \multirow{3}{*}{ Nr punktu pomiaru } & \multicolumn{10}{|c|}{ Zawartość składników stopowych, \% } \\
\hline & $\mathrm{C}$ & $\mathrm{Mn}$ & Si & $\mathrm{P}$ & S & $\mathrm{Cr}$ & $\mathrm{Ni}$ & $\mathrm{Cu}$ & Mo & V \\
\hline & \multicolumn{10}{|c|}{$\max$} \\
\hline 1 ' & 0,33 & 1,51 & 0,43 & 0,018 & 0,015 & 0,08 & 0,41 & 0,17 & 0,01 & 0,01 \\
\hline 2' & 0,19 & 1,39 & 0,45 & 0,020 & 0,020 & 0,08 & 0,19 & 0,22 & 0,01 & 0,00 \\
\hline $3^{\prime}$ & 0,64 & 0,75 & 0,26 & 0,010 & 0,006 & 0,13 & 0,06 & 0,15 & 0,02 & 0,01 \\
\hline $4^{\prime}$ & 0,65 & 0,74 & 0,26 & 0,011 & 0,007 & 0,13 & 0,06 & 0,15 & 0,02 & 0,01 \\
\hline $7^{\prime}$ & 0,64 & 0,76 & 0,25 & 0,010 & 0,006 & 0,14 & 0,06 & 0,15 & 0,02 & 0,01 \\
\hline 3 & 0,29 & 1,49 & 0,41 & 0,017 & 0,013 & 0,09 & 0,40 & 0,18 & 0,01 & 0,00 \\
\hline 4 & 0,48 & 1,02 & 0,76 & 0,053 & 0,039 & 0,05 & 0,44 & 0,18 & 0,01 & 0,02 \\
\hline 1 & 0,64 & 0,73 & 0,27 & 0,011 & 0,007 & 0,13 & 0,07 & 0,15 & 0,02 & 0,01 \\
\hline 2 & 0,64 & 0,73 & 0,28 & 0,011 & 0,007 & 0,13 & 0,06 & 0,15 & 0,02 & 0,01 \\
\hline
\end{tabular}




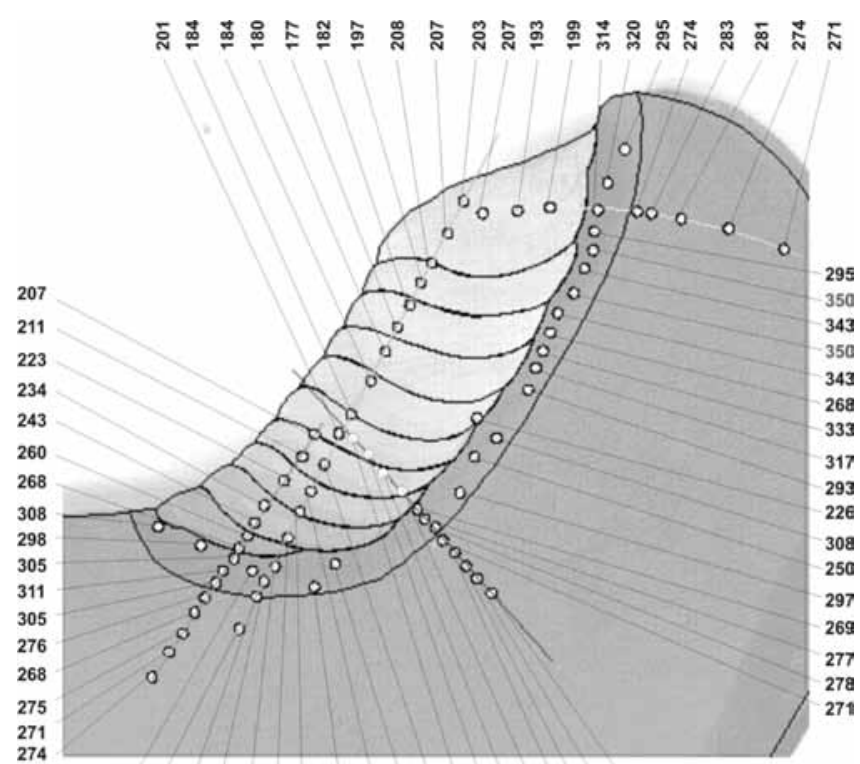

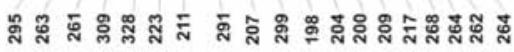

Rys. 10. Rozkład twardości HV30 w napoinie dziesięciowarstwowej wykonanej łukiem krytym na obręczy ze stali P60T

Fig. 10. Distribution of hardness HV3O in ten-layer weld metal performed with submerged arc on wheel hoop made of steel P60T

martenzytu. Występuje tam przede wszystkim perlit lub perlit z niewielką ilością ferrytu. Świadczy to o dobrze dobranych warunkach cieplnych procesu napawania.

Łatwo można zauważyć, że twardość warstw w napoinie dziesięciowarstwowej wynosząca $177 \div 268$ HV30 jest wyraźnie niższa niż w napoinie ośmiowarstwowej (230 $\div 298$ HV30). Ponadto w pierwszym przypadku twardość ostatniej warstwy wynosząca 193 $\div 207$ HV30 jest znacznie niższa niż odpowiednia twardość warstwy na

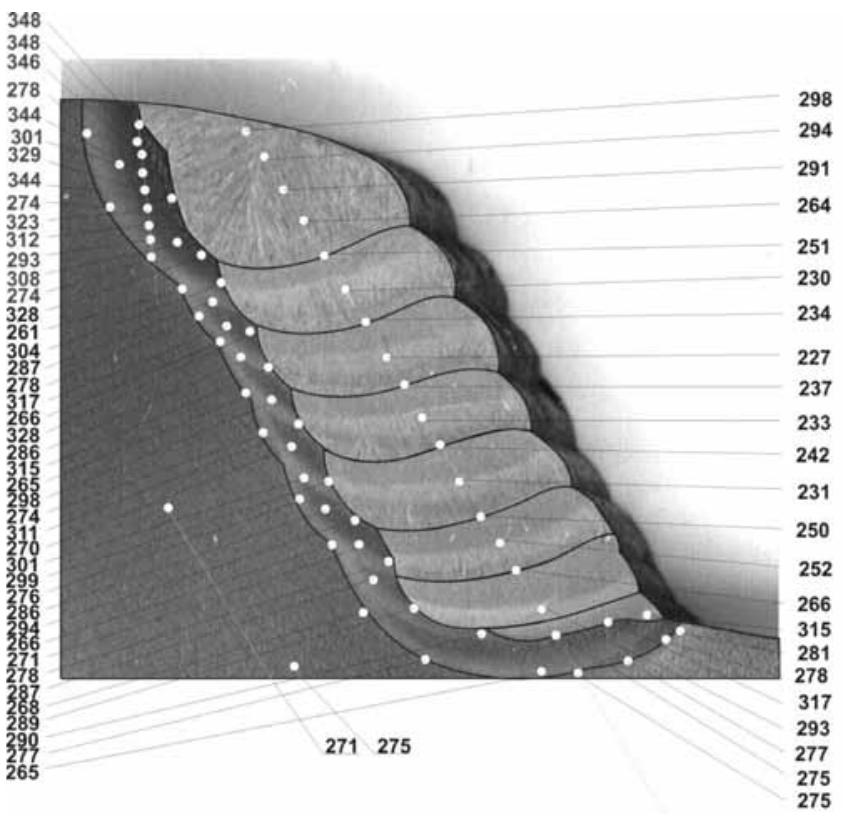

Rys. 11. Rozkład twardości HV30 w napoinie ośmiowarstwowej wykonanej łukiem krytym na obręczy ze stali P60T

Fig. 11. Distribution of hardness HV30 in an eight-layer weld metal performed with submerged arc on wheel hoop made of P60T steel

drugiej obręczy, która wynosi $251 \div 298$ HV30. Powodem tak wyraźnych różnic w twardości napoin jest inny stopień wymieszania materiału stopiwa z materiałem obręczy, wynikający z wybranych parametrów napawania. Warstwy napoiny dziesięciowarstwowej układano z mniejszym wtopieniem, przez co w napoinie większy udział ma miękki materiał spoiwa, co wyraźnie można stwierdzić, porównując twardość napoin $\mathrm{z}$ twardością materiału ro-

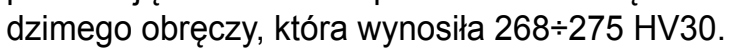

\section{Wnioski}

$\mathrm{Na}$ podstawie przeprowadzonych badań można stwierdzić, że obręcze kolejowych zestawów kołowych wykonane ze stali P60T można regenerować metodą napawania automatycznego łukiem krytym.

Widoczne różnice twardości w napoinach obu obręczy wynikają z różnego wymieszania stopiwa z materiałem podłoża, co zostało potwierdzono wynikami analizy chemicznej napoin i wynikami pomiarów twardości. Każda układana warstwa napoiny oddziałuje cieplnie na warstwę poprzednią oraz jej strefę wpływu ciepła na głębokości ok. $2 \div 3 \mathrm{~mm}$ pod ściegiem.

Obręcze ze stali P60T przed napawaniem wymagają podgrzewania wstępnego do temperatury $240^{\circ} \mathrm{C}$. Temperatura ta musi być ściśle kontrolowana i przestrzegana w procesie napawania. Obniżenie temperatury obręczy podczas napawania prowadzi do znacznego wzrostu twardości w SWC zwłaszcza pod pierwszą i ostatnią warstwą.

Warunki napawania podczas całego procesu muszą być dokładnie kontrolowane. Nawet niewielkie różnice $w$ natężeniu prądu i temperaturze podgrzewania wstępnego obręczy mogą prowadzić do znacznych różnic twardości w spoinie oraz SWC.

Naddatek napoiny na obróbkę skrawaniem powinien przewidywać usunięcie materiału toczeniem na grubości przynajmniej $2 \mathrm{~mm}$, co pozwoli na zebranie niewyżarzonej pierwszej warstwy i strefy wpływu ciepła pod pierwszą warstwą.

Celowe byłoby rozważenie wygrzewania palnikiem napawanej obręczy (obrzeża) przez czas $1 \div 2 \mathrm{~h}$ po zakończeniu procesu napawania utrzymując temperaturę ok. $230 \div 240^{\circ} \mathrm{C}$. Zabieg ten ma na celu umożliwienie wydzielania się wodoru z SWC oraz ze spoiny. Dla wprowadzenia jak najmniejszej ilości wodoru należy również ściśle przestrzegać temperatury suszenia topnika.

Należy rozważyć możliwość zastosowania innych drutów pozwalających otrzymać warstwy o większej twardości i odporności na ścieranie. Podwyższenie twardości warstw do takiej, jaką ma materiał obręczy, pozwoliłoby uzyskać zwiększenie odporności na zużycie ścierne napoiny zbliżone do odporności stali P60T. 


\section{Literatura}

[1] Białucki P., Kozerski S.: Wpływ rodzaju topnika i drutu przy spawaniu łukiem krytym stali P55 na własności napoiny. Przegląd Spawalnictwa. 2002 R. 74, nr 8-10, s. 109-111.

[2] Białucki P., Kozerski S.: Możliwości napawania zestawów kołowych bez wywiązywania. Spajanie Metali i Tworzyw w Praktyce. 2005 nr 1, s. 19-23, 6 rys.

[3] Romaniszyn Z.: Wpływ konstrukcji kół normalnotorowych pojazdów szynowych na ich współdziałanie z torem. TTS nr 6-7, s. 44-48, 1995.
[4] Krasowski A.: Zwiększanie trwałości eksploatacyjnej obręczy zestawów kołowych metodą hartowania powierzchniowego obrzeża. TTS nr 11-12, s. 36-40, 1995.

[5] Możliwości regeneracyjnego zmechanizowanego napawania obręczy kolejowych zestawów kołowych. Komunikat ZDISu w Gliwicach, TTS nr 11-12, s. 35, 1995.

\section{Nowości wydawnicze}

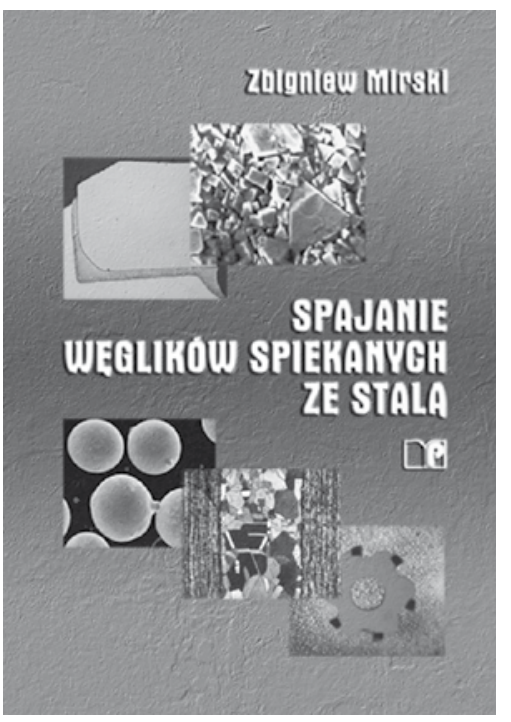

\section{Spajanie węglików spiekanych ze stalą}

Zbigniew Mirski

Format: B5, miękka okładka

Liczba stron: 369

ISBN 978-83-7493-609-5

Oficyna Wydawnicza Politechniki Wrocławskiej, Wrocław 2011

Na rynku wydawniczym ukazała się książka pt. „Spajanie węglików spiekanych ze stalą", której Autorem jest Prof. dr hab. inż. Zbigniew Mirski

Książka stanowi podsumowanie 30-letniego dorobku i doświadczeń Autora w zakresie problematyki spajania węglików spiekanych ze stalą w aspekcie wytwarzania narzędzi.

Książka ma objętość 369 stron tekstu z 277 rysunkami i 59 tabelami, zawiera przedmowę, wykaz ważniejszych oznaczeń, wstęp, 18 rozdziałów, wykaz literatury obejmujący w sumie 404 aktualnych i klasycznych pozycji źródeł, z których w ponad 60 prof. dr hab. inż. Zbigniew Mirski jest autorem lub współautorem. Wykaz literatury zawiera również wykaz norm, katalogi i strony www.

Książka dotyczy aktualnej i złożonej problematyki procesów spajania stali z węglikami spiekanymi. Problematyka spajania materiałów o różnym składzie chemicznym i właściwościach jest we współczesnych źródłach stosunkowo słabiej opracowana i stanowi przedmiot aktualnego zainteresowania licznych ośrodków badawczych, między innymi w obszarze spajania stopów żelaza z węglikami spiekanymi.

W książce Autor charakteryzuje strukturę i właściwości węglików spiekanych, problemy doboru materiałów na korpusy narzędzi dla węglików spiekanych oraz metody spajania węglików spiekanych ze stalą: klejenia, lutowania, zgrzewania i spawania wraz $z$ charakterystyką spoiw, podstaw fizycznych procesów elementarnych zachodzących podczas spajania, wpływu warunków i parametrów spajania na przebieg procesu, oraz analizą struktury i właściwości złączy.

Autor dokonał również porównania omawianych metod lutowania, scharakteryzował typowe dla lutowania twardego niezgodności, metody badań połączeń lutowanych i przykłady zastosowań przemysłowych zastosowań narzędzi z węglikami spiekanymi.

Książka stanowi atrakcyjny i wartościowy monograficzny materiał naukowy oparty w znacznym stopniu na pracach badawczych Autora, ma również walory dydaktyczne.

Treści przedstawione $\mathrm{w}$ recenzowanej monografii mogą być jak najbardziej przydatne dla szerokiego kręgu konstruktorów, technologów i specjalistów z zakresu inżynierii materiałowej, inżynierii spawania a również dla specjalistów w zakresie konstruowania i wytwarzania.

Książka „Spajanie węglików spiekanych ze stalą”, autorstwa prof. dr hab. inż. Zbigniewa Mirskiego stanowi atrakcyjny i wartościowy monograficzny materiał naukowy dotyczący charakterystyki technik spajania stali z węglikami spiekanymi i silnie akcentujący znaczenie i rolę praktycznych zastosowań tej techniki w spawalnictwie

Jerzy Nowacki Zachodniopomorski Uniwersytet Technologiczny w Szczecinie 